Kumawula, Vol. 4, No.1, April 2021, Hal 87 - 91

DOI: https://doi.org/10.24198/kumawula.v4i1.32019

ISSN 2620-844X (online)

Tersedia online di http://jurnal.unpad.ac.id/kumawula/index

\title{
PENERAPAN PROGRAM DARMASAN (SADAR MASKER PADA ANAK-ANAK) DALAM UPAYA MENGURANGI PENYEBARAN COVID-19
}

\author{
Dianne Amor Kusuma \\ Departemen Matematika FMIPA Universitas Padjadjaran \\ Email : amor@unpad.ac.id
}

\begin{abstract}
Recently, the spread of Covid-19 in Indonesia has been very high. It is due to the non-compliance of most people with the government's appeal to always carry out the $3 M$ movement (wearing a mask, social distancing, and washing hands using soap with flowing water). The activity of implementing the Darmasan (Mask Awareness for Children) program is carried out in order to assist the government in its efforts to break the chain of Covid-19 spreading, especially among children. The focus of attention in this activity is the children and their parents who still ignore the government's appeal to always wear masks during this pandemic. Based on the results of interviews, surveys and observations carried out, it was found that there were children in several areas in Indonesia who had not realized the negative impacts of not wearing a mask when doing activities outside during this pandemic. To overcome this problem, the method used is to provide understanding and assistance so that they realize the importance of wearing a mask, especially for children, who are very vulnerable to being exposed to Covid-19. The result of implementing the Darmasan program is a very positive response from parents who feel helped by this activity and hope that this activity is carried out regularly.
\end{abstract}

Keywords: Children, Darmasan, The Spread of Covid-19

\begin{abstract}
ABSTRAK
Akhir-akhir ini penyebaran Covid-19 di Indonesia sangat tinggi. Ini disebabkan ketidakpatuhan sebagian besar masyarakat terhadap himbauan pemerintah untuk selalu melakukan gerakan 3M (memakai masker, menjaga jarak, dan mencuci tangan menggunakan sabun dengan air mengalir). Kegiatan penerapan program Darmasan (Sadar Masker pada Anak-Anak) ini dilaksanakan dengan tujuan untuk membantu pemerintah dalam upaya memutus rantai penyebaran Covid-19 terutama di kalangan anak-anak. Yang menjadi fokus perhatian dalam kegiatan ini adalah anak-anak dan para orang tua yang masih mengabaikan himbauan pemerintah untuk selalu memakai masker di masa pandemi ini. Berdasarkan hasil wawancara, survei, dan observasi yang dilakukan, ditemukan bahwa masih terdapat anak-anak di beberapa daerah di Indonesia yang belum menyadari dampak negatif tidak memakai masker ketika beraktivitas di luar rumah, di masa pandemi ini. Untuk mengatasi masalah tersebut, metode yang dilakukan adalah memberikan pemahaman dan pendampingan agar mereka menyadari pentingnya memakai masker, terutama pada anak-anak, yang sangat rentan terpapar Covid-19. Hasil dari penerapan program Darmasan ini adalah respon yang sangat positif dari para orang tua yang merasa terbantu dengan adanya kegiatan ini dan berharap agar kegiatan ini dilakukan secara berkelanjutan.
\end{abstract}

Kata kunci: Anak-Anak; Darmasan; Penyebaran Covid-19

\section{PENDAHULUAN}

Hampir satu tahun Indonesia dihadapkan pada musibah nasional, yang juga merupakan musibah bagi seluruh wilayah di muka bumi ini, yakni pandemi Covid-19, yang berdampak pada segala aspek kehidupan (Gunawan \& Kusuma, 2021; United Nations, 2020). Covid-19 adalah virus yang sangat ganas, yang berasal dari Wuhan (Lupton, 2021). 
Virus ini sangat menular dan dapat menyerang bayi, balita, anak-anak, orang dewasa,lansia, ibu hamil, dan ibu yang sedang menyusui (Lawrenche et al., 2020) sehingga tak sedikit yang menjadi korban dari keganasan virus ini, mulai dari kalangan anak-anak hingga orang dewasa. Sejauh ini, belum ditemukan obat khusus untuk menyembuhkan Covid-19 dan vaksinnya pun baru didistribusikan di Indonesia awal tahun 2021, serta masyarakat masih harus bersabar untuk menunggu giliran menerima vaksin dan tetap menjaga kesehatan agar tidak terpapar Covid-19.

Namun pada kenyataannya, penyebaran Covid-19 di Indonesia pada bulan Januari 2021 mengalami pelonjakan yang sangat tajam (sekitar $68.92 \%$ ), yang disebabkan sebagian masyarakat tidak disiplin menerapkan protokol kesehatan. Wujud ketidakdisiplinan masyarakat tersebut terlihat dari masih banyak masyarakat yang beraktivitas di luar rumah dan di tempat-tempat umum tanpa memakai masker, berkerumun tanpa menjaga jarak, serta mengabaikan himbauan pemerintah untuk melakukan gerakan 3M (memakai masker, menjaga jarak, dan mencuci tangan menggunakan air mengalir). Selain itu, masih banyak anak-anak yang dibiarkan beraktivitas di luar rumah dan berada di tempat-tempat umum (supermarket, arena bermain, dan pusat pertokoan) tanpa memakai masker.

Sejak pandemi Covid-19 mulai melanda seluruh penjuru dunia, World Health Organization (WHO) menganjurkan kepada seluruh masyarakat untuk memakai masker, baik masker medis maupun non medis dalam upaya memutus rantai penyebaran Covid-19 karena penggunaan masker dapat mencegah penyebaran percikan yang dapat menyebabkan infeksi dari orang yang terinfeksi, kepada orang lain (Munthe et al., 2020). Masker juga merupakan alat yang dianggap efektif untuk memutus rantai penyebaran Covid-19 (Hasiche, et al., 2020). WHO menyarankan beberapa hal yang berkenaan dengan pemakaian masker yang tepat sebagai berikut: a) Sebaiknya membersihkan tangan dengan handsanitizer atau dengan sabun pada air mengalir sebelum memakai masker; b) ketika memakai masker, pastikan masker menutupi hidung dan mulut, serta tidak ada celah antar masker dan wajah; c) jangan menyentuh masker saat digunakan; d) sebaiknya masker segera diganti setelah digunakan selama 4 jam (untuk masker, sebaiknya langsung dibuang di tempat tertutup dan untuk masker non medis segera dicuci setelah digunakan selama 4 jam); dan e) ketika melepas masker, jangan menyentuh bagian depan masker namun lepaskan dari belakang. Jika tanpa sengaja tersentuh, segeralah mencuci tangan dengan sabun. Berdasarkan anjuran tersebut, maka perlu dilakukan upaya untuk memberikan pemahaman kepada masyarakat Indonesia terutama anak-anak yang rentan terpapar Covid-19 atau para orang tua agar memiliki kesadaran untuk selalu memakai masker di masa pandemi ini.

Berdasarkan survei awal, wawancara, dan observasi awal yang dilakukan penulis dan para mahasiswa KKN di beberapa lokasi di Kuningan, Cirebon, Jakarta, Tangerang, Bekasi, Karawang, Bogor, Serang, Bandung, Cimahi, Sumedang, Pangandaran, Magelang, Pekanbaru, dan Banda Aceh pada tanggal 12-20 Januari 2021, menunjukkan bahwa masih ditemukan sekitar $50 \%$ anak-anak yang masih beraktivitas di luar rumah tanpa memakai masker, serta para orang tua yang membawa anak-anak mereka ke tempat-tempat umum (supermarket, arena bermain, dan pusat perbelanjaan) tanpa memakai masker sehingga mereka berpeluang terpapar Covid-19. Oleh karena itu untuk mengurangi penyebaran Covid-19 di kalangan anak-anak, maka diterapkan program Darmasan (Sadar Masker pada Anak-Anak).

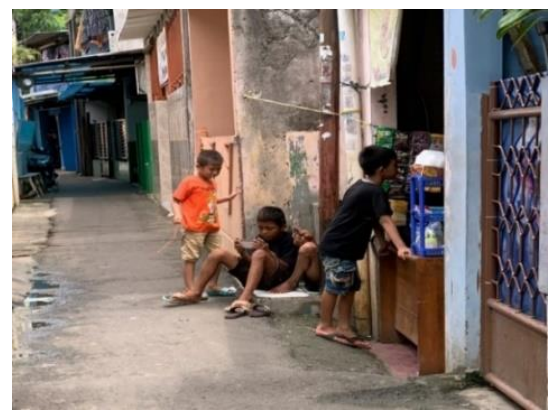

Gambar 1. Anak-anak yang beraktivitas di luar rumah tanpa memakai masker 


\section{METODE}

Kegiatan penerapan program Darmasan ini dilakukan sebagai upaya untuk membantu mengurangi penyebaran Covid-19 di kalangan anak-anak ini dilaksanakan di beberapa lokasi di Kuningan, Cirebon, Jakarta, Tangerang, Bekasi, Karawang, Bogor, Serang, Bandung, Cimahi, Sumedang, Pangandaran, Magelang, Pekanbaru, dan Banda Aceh. Kegiatan ini dilaksanakan menggunakan metode wawancara, survei, dan observasi. Adapun yang menjadi sasaran dari kegiatan ini adalah anakanak dan para orang tua.

Kegiatan penerapan program Darmasan ini meliputi beberapa tahapan, yaitu tahap persiapan, pelaksanaan, dan evaluasi kegiatan. Persiapan yang dilakukan dalam kegiatan ini adalah sebagai berikut: i) melakukan survei awal di beberapa lokasi tempat berkumpulnya anak-anak dan para orang tua yang memiliki anak berusia 0-12 tahun; ii) melakukan wawancara terhadap anak-anak dan/atau para orang tua yang memiliki anak berusia 0-12 tahun; iii) melakukan observasi di beberapa lokasi tempat berkumpulnya anak-anak dan para orang tua yang memiliki anak berusia 0-12 tahun, seperti: taman bermain, tempat mengaji, dan minimarket; iv) membuat rencana kegiatan pendampingan yang akan dilakukan; v) membuat desain pamflet program Darmasan; dan vi) menentukan jadwal pelaksanaan kegiatan pendampingan. Adapun pelaksanaan kegiatan ini meliputi: 1) menyebarkan pamflet program Darmasan; 2) memberikan pendampingan dengan cara memberikan pemahaman tentang pentingnya memakai masker berupa pemutaran film, mendongeng, permainan-permainan, dan webinar; dan 3) membagikan masker-masker bergambar yang menarik bagi anak-anak. Selanjutnya, dilakukan tahap evaluasi untuk mengetahui sejauhmana penerapan program Darmasan dapat membantu mengurangi penyebaran Covid-19 khususnya di kalangan anak-anak. Indikator keberhasilan tahap ini dilihat dari penurunan jumlah pasien Covid-19 berusia 0-12 tahun di lokasi-lokasi tempat diterapkannya program Darmasan ini.

\section{HASIL DAN PEMBAHASAN}

Kegiatan penerapan program Darmasan ini meliputi beberapa tahapan, yaitu tahap persiapan, pelaksanaan, dan evaluasi kegiatan. Persiapan yang dilakukan dalam kegiatan ini adalah sebagai berikut: i) melakukan survei awal di beberapa lokasi tempat berkumpulnya anak-anak dan para orang tua yang memiliki anak berusia 0-12 tahun; ii) melakukan wawancara terhadap anak-anak dan/atau para orang tua yang memiliki anak berusia 0-12 tahun; iii) melakukan observasi di beberapa lokasi tempat berkumpulnya anak-anak dan para orang tua yang memiliki anak berusia 0-12 tahun; iv) membuat rencana kegiatan pendampingan yang akan dilakukan; v) membuat desain pamflet program Darmasan; dan vi) menentukan jadwal pelaksanaan kegiatan pendampingan. Adapun pelaksanaan kegiatan ini meliputi: 1) menyebarkan pamflet program Darmasan; 2) memberikan pendampingan dengan cara memberikan pemahaman tentang pentingnya memakai masker berupa pemutaran film, mendongeng, permainan-permainan, dan webinar; dan 3) membagikan masker-masker bergambar yang menarik bagi anak-anak. Selanjutnya, dilakukan tahap evaluasi untuk mengetahui sejauhmana penerapan program Darmasan dapat membantu mengurangi penyebaran Covid-19 khususnya di kalangan anak-anak. Indikator keberhasilan tahap ini dilihat dari penurunan jumlah pasien Covid-19 berusia 0-12 tahun di lokasi-lokasi tempat diterapkannya program Darmasan ini.

Dari hasil survei, wawancara, dan observasi yang telah dilakukan, diperoleh data bahwa di beberapa tempat di Kuningan, Cirebon, Jakarta, Tangerang, Bekasi, Karawang, Bogor, Serang, Bandung, Cimahi, Sumedang, Pangandaran, Magelang, Pekanbaru, dan Banda Aceh, masih ditemukan anak-anak yang tidak memakai masker ketika beraktivitas di luar rumah, seperti di supermarket, arena bermain, dan pusat pertokoan. Hal itu disebabkan beberapa faktor, yakni masih kurangnya kesadaran mereka tentang pentingnya memakai masker, orang tua 
yang terlalu sibuk sehingga kurang mengawasi anak-anaknya ketika berada di luar rumah tidak memakai masker, masih kurangnya pemahaman yang diberikan oleh orang tua mereka tentang pentingnya memakai masker, anak-anak merasa kurang nyaman memakai masker, dan orang tua merasa kesulitan memberikan pemahaman pada anak-anak mereka tentang pentingnya memakai masker. Untuk itu perlu diupayakan solusi agar anak-anak menyadari bahwa mereka berpeluang terpapar Covid-19 jika tidak memakai masker di masa pandemi ini (Supriatun et al., 2020).

Salah satu solusi yang dapat membantu memecahkan masalah tersebut adalah dengan penerapan program Darmasan, yaitu dengan cara memberikan pendampingan pada anakanak dan para orang tua mengenai pentingnya memakai masker di masa pandemi ini sehingga rantai penyebaran Covid-19 dapat terputus. Kegiatan pendampingan ini dilaksanakan sebanyak dua kali, yakni pada tanggal 20 dan 28 Januari 2021. Materi pendampingan yang diberikan meliputi: 1) memberikan pemahaman tentang bahaya Covid-19 dan cara penularan serta media penularannyanya melalui dongeng/cerita yang menarik dan interaktif; 2) memberikan pemahaman tentang pentingnya memakai masker dalam upaya memutus rantai penyebaran Covid-19 melalui pemutaran film; 3) mengadakan permainan-permainan menarik yang memuat pemahaman tentang bagaimana cara "berperang" melawan Covid-19; dan 4) membagikan masker-masker bergambar yang menarik bagi anak-anak. Pendampingan ini diikuti oleh 375 anak yang tersebar di 15 lokasi di Kuningan, Cirebon, Jakarta, Tangerang, Bekasi, Karawang, Bogor, Serang, Bandung, Cimahi, Sumedang, Pangandaran, Magelang, Pekanbaru, dan Banda Aceh.

Penerapan program Darmasan ini meliputi beberapa tahapan kegiatan meliputi: a) minggu pertama, melakukan survei awal, wawancara, dan observasi terhadap anak-anak dan/atau para orang tua, dengan tujuan untuk mengidentifikasi permasalahan yang ada berkenaan dengan kesadaran bermasker pada anak-anak; b) minggu ke-2 dan ke-3, mengumpulkan data, membuat desain program kegiatan pendampingan yang akan dilakukan sebagai penawaran solusi dari permasalahanpermasalahan yang telah diidentifikasi pada minggu pertama, serta melaksanakan pendampingan; c) minggu ke-4, menginventarisasi foto-foto dan video kegiatan, menyusun laporan, serta melakukan evaluasi dari keseluruhan kegiatan penerapan program Darmasan yang telah dilakukan.

Program Darmasan ini ditawarkan sebagai solusi dari permasalahan yang telah diidentifikasi, yakni tingkat kesadaran anakanak (juga para orang tua) mengenai dampak buruk tidak memakai masker ketika berkegiatan di luar rumah atau di tempat-tempat umum yang masih rendah, sehingga dapat memperluas penyebaran Covid-19 di kalangan anak-anak, yang disebabkan beberapa faktor. Dengan adanya kegiatan pendampingan yang dilakukan, tanggapan masyarakat yakni para orang tua sangat positif dan mendukung penerapan program Darmasan ini, karena dapat membantu mereka untuk menanamkan kesadaran bermasker pada anak-anak mereka. Begitu pun dengan anak-anak, mereka sangat antusias dan bersemangat mengikuti kegiatan pendampingan yang dilakukan. Hal ini terlihat dari partisipasi anak-anak dan para orang tua yang mengikuti kegiatan ini.

\section{SIMPULAN}

Berdasarkan kegiatan penerapan program Darmasan yang telah dilakukan ini, dapat disimpulkan bahwa masih terdapat sebagian anak-anak yang belum memiliki kesadaran tentang pentingnya memakai masker ketika berkegiatan di luar rumah di masa pandemi Covid-19. Kondisi ini disebabkan beberapa faktor, yaitu masih kurangnya kesadaran mereka tentang pentingnya memakai masker, orang tua yang terlalu sibuk sehingga kurang mengawasi anak-anaknya ketika berada di luar rumah tidak memakai masker, masih kurangnya pemahaman yang diberikan oleh orang tua mereka tentang pentingnya memakai masker, anak-anak merasa kurang nyaman memakai masker, dan orang tua merasa 
kesulitan memberikan pemahaman pada anakanak mereka tentang pentingnya memakai masker. Hal ini didukung oleh data yang diperoleh melalui observasi, survei, dan wawancara terhadap beberapa anak-anak dan para orang tua di beberapa tempat di Kuningan, Cirebon, Jakarta, Tangerang, Bekasi, Karawang, Bogor, Serang, Bandung, Cimahi, Sumedang, Pangandaran, Magelang, Pekanbaru, dan Banda Aceh.

Dengan diselenggarakannya pendampingan terhadap anak-anak dan para orang tua, mereka dapat memahami betapa berbahayanya Covid19, memiliki kesadaran yang tinggi tentang pentingnya memakai masker, serta memahami dan menyadari bahwa memakai masker dapat mengurangi penyebaran Covid-19. Untuk menjaga keberlanjutannya, maka sebaiknya penerapan program Darmasan ini pun dilakukan di beberapa lokasi lain di Indonesia agar Covid19 dapat segera musnah dari bumi Indonesia ini.

\section{UCAPAN TERIMA KASIH}

Paper ini merupakan hasil Pengabdian kepada Masyarakat dalam kegiatan KKN Integratif Virtual 2021. Ucapan terima kasih disampaikan kepada Rektor Universitas Padjadjaran, Direktorat Riset, Pengabdian kepada Masyarakat dan Inovasi, tim Ad hoc KKN Universitas Padjadjaran, serta tim mahasiswa KKN Integratif Virtual 2021 yakni: Riza Gunawan, Avisa Kemala Puspitasari, Salsabila Mulantara, Agung Anggara Rudini, Fadhila Irwani Shafira, Fania Nur Hamidah, Devita Farah Nabila, Salsabila, Dary Alwan Huwaidi, Syahrul Febrian Hasbulah, Fahmi Muhammad Farhan, Galuh Hanesty Gunawan, Nur Ali Apriyanto, Cut Shabirah Miadarma, Aldira Gemilang, Imam Andhika Poetra, Azzura Zahra Zahira, Daffa Andita Kautsar, Arsal Fahruji Yusuf, dan Wilda Nichairin, serta anakanak dan masyarakat yang telah berpartisipasi dalam kegiatan ini.

\section{DAFTAR PUSTAKA}

Cahyati, N. \& Kusumah, R. (2020). Peran Orang Tua dalam Menerapkan Pembelajaran di Rumah saat Pandemi
Covid-19. Jurnal Golden Age Universitas Hamzanwadi, 4(1): 152-159.

Gunawan, W., \& Kusuma, D. A. (2021). Kegiatan Pemberian Bantuan Sosial Pandemi Covid-19 Di Desa Sekitar Kampus Unpad Jatinangor. Kumawula: Jurnal Pengabdian Kepada Masyarakat, 3(3), 465. https://doi.org/10.24198/kumawula.v3i3. 28626

Haischer, M. H., Beilfuss, R., Hart, M. R., Opielinski, L., Wrucke, D., Zirgaitis, G., Uhrich, T. D., \& Hunter, S. K. (2020). Who is Wearing a Mask? Gender, Age, and Location Related Differences during the Covid-9 Pandemic. Journal Plos One, 0240785: 1-12.

Lawrenche, F., Wulandari, N., Ramadhan, N., Rahayu, F., Bakhtiar, M. A., \& Nurrachmawati, A. (2020).

Pemberdayaan Masyarakat Dimasa Pandemi Covid-19 Pada Ikatan Remaja Masjid RT.04 Loa Kulu. Kumawula: Jurnal Pengabdian Kepada Masyarakat, 3(3), 429-434. https://doi.org/10.24198/kumawula.v3i3. 28007

Lupton, D. (2021). CONTEXTUALISING COVID-19 Sociocultural perspectives on contagion. In D. Lupton \& K. Willis (Eds.), The COVID-19 Crisis Social Perspectives (pp. 14-24). Oxon: Routledge.

Munthe, S. A., Manurung, J., \& Sinaga, L. R. V. (2020). Penyuluhan dan Sosialisasi Masker di Desa Sifahandro Kecamatan Sawo sebagai bentuk Kepedulian terhadap Masyarakat di Tengah Mewabahnya Virus Covid 19. Jurnal Abdimas Mutiara, 1(2): 115-123.

Supriatun, E., Insani, U., \& Ni'mah, J. (2020). Edukasi Pencegahan Penularan Covid 19 di Rumah Yatim Kota Tegal. JABI: Jurnal Abdimas Bhakti Indonesia, 1(2): $1-14$.

United Nations. (2020). Five things you should know now about the COVID-19 pandemic. Retrieved April 17, 2020, from United Nations website: https://news.un.org/en/story/2020/03/105 9261 